\title{
Reverse-Inclusion Continuing Education Program at College Aimed at Students with Intellectual and Developmental Disabilities: Program Implementation
}

Kaelin N. Rubenzer, B.S. ${ }^{1,2}$, Tamara H. Shetron, Ph.D. ${ }^{2,3}$, and Jonathan T. Pierce, Ph.D., ${ }^{1,2,4}$

\section{Short title: Reverse-Inclusion Continuing Education Program}

${ }^{1}$ Department of Neuroscience, Center for Learning \& Memory, College of Natural Sciences, University of Texas, Austin

${ }^{2}$ Lifelong Learning with Friends, Joshua's Stage, Austin, TX 78750

${ }^{3}$ Texas State University, Department of Curriculum and Instruction, Developmental Education

${ }^{4}$ UT Informal Classes, University of Texas, Austin,

\section{Author Note}

Kaelin N. Rubenzer ORCID ID: 0000-0001-6057-7416

Tamara H. Shetron ORCID ID: 0000-0002-6491-6902

Jonathan T. Pierce ORCID ID: 0000-0002-9619-4713

Correspondence concerning this article should be addressed to Dr. Jonathan T. Pierce,

Department of Neuroscience, The University of Texas at Austin, 2506 Speedway NMS 5.234,

Mail code C7350, Austin, TX 78712-0805. Email: jonps@utexas.edu Phone: 512-529-9331 


\title{
Reverse-inclusion Continuing Education Program at College Aimed at Students with Intellectual and Developmental Disabilities: Program Implementation
}

\begin{abstract}
Many post-secondary education programs foster self-sufficiency, intellectual growth, and employment skills for adults with intellectual and developmental disabilities (IDD). However, these programs do not usually introduce adults with IDD to the broad range of academic subjects that their neurotypical peers take in college. Thus, a decade ago we developed a reverseinclusion, continuing-education program at University of XXXXX aimed at adults with IDD. Students with and without IDD take courses together on campus in science, humanities, and selfsufficiency skills. We describe how we designed and implemented our program which serves $>200$ students annually. This can inform the development of similar programs in other locations.
\end{abstract}

Key words: reverse inclusion; post-secondary education; college; continuing education

In response to poor academic and employment outcomes for people with intellectual and developmental disability (IDD) at the postsecondary level, inclusive postsecondary education (PSE) programs designed to support and promote inclusion in college are being created. To date, 310 programs in the U. S. are listed on the Think College website (2021) and in 2008, the Higher Education Opportunity Act defined students with Intellectual Disability (ID) as a distinctive college student population. Although programs develop in different ways and under different situations, they typically focus on providing inclusive experiences such as equal access to campus facilities and activities, campus living. They also include specific programs and/or 
courses of study. Research indicates the benefits of these inclusive college experiences in academic and social growth as well as better employment outcomes (Folk et al., 2012; Grigal et al., 2020; Qian et al., 2018).

There are many reasons to pursue education at the postsecondary level. Some students are expressly seeking credentials and training for employment, while other chose a liberal arts approach focusing on developing as individuals and gaining a better understanding of the world around them. Neither choice need be exclusive of the other (Giroux, 2012). Continuing education, or "lifelong learning" courses are one way to provide postsecondary education opportunities that are less rigid than college degrees or certificate programs. Continuing education courses may be part of intentional professional development or they may be taken for personal enrichment. Many colleges offer non-credit, continuing education courses which are generally low cost, responsive to adult learners' individual needs, convenient in both location and time, and feature a wide variety of topics (Tasçi \& Titrek, 2019). Continuing education provides an opportunity for lifelong learners from a variety of backgrounds to continue to evolve and learn across the lifespan, an opportunity that Toffler (1970) deems essential for $21^{\text {st }}$ century learners who are navigating a constantly shifting technological and information rich world. Providing these same learning opportunities across the lifespan for adults with IDD is crucial for tapping into their ability to grow and develop across the lifespan (Karmiloff-Smith, 2009).

To provide adults with IDD an inclusive learning opportunity, we developed a continuing education program based on the University of XXXX campus. A key feature of our programs is the use of reverse-inclusion with neurotypical college students from STEM and education fields. A strategy for intentional inclusion, reverse inclusion, sets our program apart from typical continuing education and for-credit courses. An approach typically associated with K-12 
education, reverse inclusion benefits students with IDD because it encourages the instructor to teach a wider range of information to students with diverse abilities, and allows powerful peer learning between people with and without IDD.

In this descriptive study, we focus on the conceptualization and implementation of our inclusive continuing education. We demonstrate how taking advantage of existing campus resources to serve people with IDD coupled with the use of a form of inclusion with peer supports, reverse inclusion, can greatly expand postsecondary options for students with IDD while lowering the stigma often associated with this group for neurotypical college students and other campus personnel (Ditchman et al., 2013). Our expanded lifelong learning opportunities uphold the tenets of Wolfensberger's social role valorization (1998) by providing lifelong education opportunities for students with IDD in socially valued places with their peer group.

We begin with a explanation of our methodology followed by the descriptive section which includes (1) the founder's narrative, (2) program design and implementation, (3) student attendance, outcomes, and feedback, (4) other stakeholder feedback, and (5) lessons learned. We conclude with recommendations for program replication and suggestions for future studies.

\section{Methodology}

This case study provides a description of our reverse-inclusion continuing education program that began in fall 2010 at the University of XXXX. Descriptive analysis helps researchers and other stakeholders develop a better understanding of an educational phenomenon in order to identify and define specific characteristics of the population(s) being served as well as features of the program implementation that are effective (Loeb et al., 2017). Such description can later support causal research in similar scenarios, and can serve as a template for replication at other institutions of higher education. 
Descriptive data comes from the experiences of the support staff, vested stakeholders (e.g., students with and without IDD, program staff, instructors, and care givers), and program records (e.g., attendance records, course descriptions, and syllabi) which were collected over a decade of program existence. To differentiate between students with IDD and those without, we refer to them here as students with IDD or neurotypical students. We use the term students to indicate both groups together.

Although primarily descriptive in nature, we identify program facilitators and barriers and provide evidence of program outcomes derived from student and other stakeholder feedback in the "lessons learned" section. In-depth analysis of student outcomes will be the focus of a subsequent study.

\section{Context}

Since the No Child Left Behind Act of 2001, more families have been working with educators to gain access to inclusive learning in academic subjects in K-12 education. In parallel, the hundreds of PSE programs have emerged for adults with IDD on US college campuses. Most programs emphasize job training, many PSE programs over learning for the sake of learning across a broad range of sophisticated academic topics - a goal that many universities and neurotypical students highly value. In addition, the restricted program length of most PSE programs limit the maintenance of academic skills and friendships into adulthood. Many adults with IDD are often idle, socially isolated, and infantilized in their community. Thus, some families feel that their students with IDD enrolled in PSE programs should be offered opportunities to discuss and learn mature topics that are popular with neurotypical college students and in a longer continuing-education format.

\section{Program Implementation}

\section{Overview}

Our program was founded to promote inclusion for lifelong learning and friendship building with neurotypical college peers in a university setting. We offer courses on a variety of diverse academic, 
cultural, and personal-development topics to adults with IDD who learn alongside neurotypical college students in a 2:1 reverse-inclusion format. To engage students with and without IDD in learning sophisticated topics together, our courses introduce topics unfamiliar to both groups and familiar topics approached from a new perspective (Table 1).

Courses last six weeks and are offered year-round in the evenings on weekdays and Sunday afternoons. Each course consists of six classes that meet once per week. All classes start with students meeting at a café on campus where they converse freely for the first half hour. The instructor facilitates this social period which also serves as a time buffer for late arrivals. Students then go together to a classroom in an adjacent building. Here, they engage interactively on the topic of the day.

Courses are offered à la carte at $\$ 125$ each to students with IDD. Course offerings with descriptions are advertised to the general public on our continuing education department website which is called CONTIN_ED_PROGRAM. Course fees fund administrative overhead and salaries for instructors (typically $\$ 720$ per course). Neurotypical students do not pay for the courses but receive required or optional volunteer credit through their courses on special education at the university.

\section{Reverse-inclusion format}

A critical and unique aspect of our continuing education program is the reverse-inclusion format. This allows students with IDD to learn not only from the instructor, but also benefit in multiple ways from their neurotypical peers. Peers are taught to serve five intentional and important roles in these courses. 1.) Most neurotypical students come expecting to mentor students with IDD in learning class objectives. Instructors guide neurotypical students to provide mentoring that is not excessive. 2.) They also serve as available friends. Many students with IDD are eager to make friends, but are challenged with communication and social norms, in part due to relative isolation after high school graduation. 3.) They serve as peers that model appropriate behavior. We have found that adults with IDD appear eager to mimic 
the appropriate behavior of the neurotypical students at the cafe and in the classroom. Many students with IDD were not expected to attend PSE and may not know how to behave in a college setting. We train neurotypical students to discourage and redirect behaviors inappropriate for college such as swearing, hitting, running, noises, arguing, sharing TMI, as well as hugging, touching, and breaking personal space. 4.) Neurotypical students are expected to learn class material. This approach helps neurotypical students witness firsthand that students with IDD are indeed their classroom peers, and also that students with IDD are not as limited in learning and interests and can participate in and master advanced topics. 5.) Lastly, we plan seeds so that neurotypical students may become advocates to promote inclusion of adults with IDD as they advance in their professional careers in medicine, education, research, and more. Examples include several who took leadership positions in IDD-focused social programs, and one who is beginning to recreate our program at a small college in the northeast.

\section{Program Institutionalization}

Our program grew in distinct phases represented by the addition of different types of students, administration, instructors, and funding (Table 2). Initially in 2010, we hosted 14 adults with DS and 7 neurotypical students. Eventually, we grew to regularly offering about 200 seats to students with IDD and 100 neurotypical students per year starting in 2015 (Figure 1). During Phase I, the founder handled instruction and administration, while the Down Syndrome Association of XXXX scheduled courses to be in synch with their programs. In Phase II, the founder sought to merge with CONTIN_ED_PROGRAM, however, they were initially reluctant to merge and did not understand the goals of the program and its potential as an untapped base for new repeat customers. To overcome this resistance, the Down Syndrome Association of XXXX offered to pay up front for all 14 seats in one course. All seats were subsequently filled with paying students. Subsequently, CONT_ED_PROGRAM overcame their hesitancy and has remained enthusiastic about the program. Students with IDD have become one of their most reliable 
subgroup of customers routinely filling course seats. This example offers a strategy to spur mutually cooperative mergers and support between existing continuing education programs and local IDD support groups. Lastly, in Phase III, the CONT_ED_PROGRAM and the founder split administration, advertising, recruiting/training instructors and neurotypical students.

For funding, student with IDD were offered courses for free during pilot Phase I as a way to encourage broad participation. Course seats were sold à la carte from Phase II onward. Advertising at transition fairs was funded by an award from the National Down Syndrome Society.

\section{Securing Space}

Usually, classrooms used for continuing education must be reserved and rented for use on our campus. However, we discovered that classrooms could be reserved and used without charge if they provided an educational experience for neurotypical students who are enrolled at our university (elaborated below). Thus, our reverse-inclusion approach allowed for this substantial cost savings in securing space. In addition to spaces reserved by students, Dr. XXXX, a professor at the institution, had the privilege to reserve a subset of classrooms and lecture halls that might have otherwise been off limits.

We use both reserved and public spaces for our classes on campus. These include:

Campus Cafe - The cafe provides inexpensive meals and snacks to the public and has a patio where students and faculty gather to study and socialize. The cafe is adjacent to a cul-de-sac where families are reassured as the instructor and other students greet their student with IDD at the start of each class.

Classrooms - Courses are primarily held in a small classroom that seats up to 25 people comfortably. The classroom has four large tables with rolling office chairs, a chalkboard, two dry-erase white boards, and an overhead projector that instructors use to display presentations, music, and videos. 
Teaching Labs - Classes that require more space are held in a science teaching lab in the same corridor. Courses focused on STEM subjects took advantage of university microscopes and other high research-quality lab equipment housed in this room.

Large Lecture Hall -Most instructors elected to hold the last day of class in a large lecture hall that can host families, caretakers, and friends for a demonstration of learning by the students.

Other venues - Some classes were held outside of the classroom. For example, our party-themed courses that focused on etiquette, social interaction, and financial planning held banquets in a gilded room in our university tower. Our basketball-themed course met at a campus gymnasium to learn from the university basketball team. Sometimes the culminating class met off campus. For instance, our country music class met at a two-step dance hall, foreign culture classes were held at a related restaurant or cultural festival, and our Broadway musical classes organized group ticket buy-ins to attend performances. Many students experienced novel locations that their families had never thought to try.

\section{Program Staff}

In addition to administrative staff, our program includes instructors and guest experts.

Instructors - During Phase I the founder taught the courses. Later, additional instructors were recruited as independent contractors from within the IDD service community, special education instructors, and transition specialists. In Phase IV, we began utilizing undergrad and graduate students who demonstrated exceptional maturity and passion for our program. Over half of our instructors have taught multiple courses, usually teaching every other semester, or once per year. About two-thirds of our instructors have been female. All instructors were background checked and trained with at least one class visit and extra consultation by the Program Coordinator. Instructors dedicated 2-5 hours to plan each class depending on experience. 
Guest experts - We have found that one way to teach new and interesting information to students with and without IDD is to bring in guest experts. Half of our classes host an expert for $\sim 25$ minutes. Guest experts have included musicians and actors who demonstrated performances, or scientists who displayed cutting edge research. We hosted experts locally in person or from afar virtually with an occasional a small honorarium (\$25-100).

\section{Students}

Students with IDD - The range of students with IDD enrolled in our program expanded through the years. For Phase I, the Down Syndrome Association of XXXX helped us recruit adults with DS who were past participants in their programs. In Phase II, we opened enrollment to adults with any type of IDD. The larger enrollment helped create a demand for a larger variety of courses. We recruited adults with autism spectrum disorder (ASD) as well as with IDD undefined in origin from assisted living centers and the general public. For Phase III, we partnered with the Autism Society of XXXX who spread word about our program. For Phase IV, we saw stable numbers and ratios of students with ASD, DS and other IDD. Students with IDD were usually 60:40 ratio of male:female in each class. In addition, a dozen students overall with ambulatory, visual, or hearing disabilities have attended on occasion with accommodations. Quality of instruction decreased if we hosted more than 14 students with IDD in typical courses.

Neurotypical students - From the beginning, we have arranged our reverse-inclusion format with a 2:1 ratio of students with and without IDD, respectively. During Phases I and II, we recruited neurotypical undergraduate and graduate students in pre-med and neuroscience fields. From Phase III onward, we recruited undergraduate students majoring in education who used participation as a required activity for their "Individual differences" education course. 
Through pre-course surveys, we found that although some of neurotypical students had limited experience with people with IDD (30\%), most (70\%) had no experience (120 students total sampled). All neurotypical students complete a mandatory background check, as well as onboard training by our program coordinator and instructors. In Phase IV, we included some university staff. Most neurotypical undergraduates were female (90:10 female:male), whereas the difference was not as stark for graduate students and staff (60:40 female:male).

\section{Proposed course planning}

We surveyed students with IDD within our program and at transition conferences and found that they were interested in the same wide range of courses as neurotypical students including history, science, culture, art, foreign languages, and more. A major organizing principle for our courses was to minimize courses that might infantilize students with IDD and we encourage instructors to teach topics that align with college student interests aligned with a standard of a university curriculum. An ideal course would take advantage of resources unique to the college environment. Instructors have creative freedom to teach topics from their personal interests and they are typically spread between humanities, STEM, and personal development.

\section{Course Structure}

The courses in the program are grounded in principles of universal design for learning and inclusion as a critical vehicle for educating for people with disabilities.

Intentional community - The first half hour of class takes place in a campus café. This provides a time for intentional activities designed to foster a sense of community amongst students and the instructor, and creates a buffer for meeting up with late comers. It also provides students with IDD the opportunity to practice money management skills, independent ordering, appropriate social behavior and an opportunity to discuss nutrition and dietary preferences and 
restrictions. This sense of independence was a newfound skill for many students, with some reporting this was the first-time ordering and paying for meals without direct supervision.

While at the café, students with IDD experience a casual college social atmosphere alongside neurotypical students. Students not enrolled in our program often engaged in organic, unrehearsed social interactions with students with IDD with enthusiasm. This environment of casual, non-structured socialization is imperative for students with IDD to achieve full inclusion in society. It preps them with complex social skills, and promotes public visibility and recognition that students with IDD belong in society, including higher education settings. Such visibility also can improve the expectations and impressions of people with IDD.

Homework-Homework was designed to be completed without assistance by all students. After moving to the classroom, students go over their homework. Students with IDD are eager to share their assignments with help from neurotypical students if necessary. Using principles of Universal Design for Learning (UDL), students can express themselves in multiple formats (i.e., writing, drawing, or printing out ideas related to classroom topics; Figure 2).

Interactive lecture - The instructor lectured interactively. Most instructors use projected slides considering the principles of UDL and emphasizing pictorial over written descriptions. Instructors circle around the classroom while teaching to help keep students engaged and to invite reluctant students to participate. Instructors send copies of class material and slides home via hard copy and/or email for additional reinforcement at home.

Whenever possible, instructors were encouraged to set up the lessons that access student's personal experiences. This allows adults with IDD to teach the neurotypical students and even guest experts based on their own experiences. For instance, in our “Alzheimer's disease" and "Parkinson's disease" courses, students with IDD shared stories from personal 
experience with grandparents who had suffered this disease or gave first-hand accounts of how it feels to get a brain MRI. In our "Drug Discovery" course, students relayed first-hand experience with levothyroxine, Lipitor, and other medicines. Simple and cutting-edge material was presented. For example, all students knew that their pets took drugs for heartworm, but they did not know how the drug ivermectin was discovered or how it acts. In lab, students examined how this drug killed normal worms, but not mutant worms that lacked the molecular receptor.

Hands-on activities and projects- Hands-on activities help the students understand abstract concepts introduced in lectures. For instance, in addition to listening to a lecture on cells and looking at pictures, students gained greater understanding by viewing glowing cells within a transparent animal or by creating model cells out of Play-Doh. These activities keep the students engaged and foster deep thinking and questioning.

Reading and writing were encouraged in all courses. For courses centered on fun nonacademic topics (e.g., Film Studies, Fun with Games, and Best of CITYNAME), students were coached to write reviews of movies, games, or tourist sites to publish as a group online. Students who cannot easily write contributed ideas verbally or with drawings.

Guest experts - It can be challenging for instructors to teach sophisticated topics at a high enough level to college students and the most engaged adults with IDD. One way to solve this problem is to have instructors lead discussions with guest experts on the course topic. We found that even special education instructors who do not have specific expertise in a topic can serve as effective translators between a guest expert and students with IDD. When neurotypical students asked the guest their own questions, unrestrained by assumed expectations of students with IDD, many students with IDD stayed engaged and learned this higher-level information. Inviting 
guests with expertise in specific topics works best when they supplement a single class for a short appearance, typically 25 minutes.

Examples of guest experts include a shakuhachi musician and semi-professional dancers who demonstrated their talents and fielded questions in our Japanese Culture course. In our American Songwriting course, local musicians shared their song writing strategies. Amazing Animals course, postdoctoral fellows visited to impress with scorpion-eating mice and magnetosensing worms.

Summary email -To keep the learning going on at home, we have instructors send a summary email after each class. Instructors are coached to explain learning objectives, and to describe concrete examples of how specific named students performed in class socially and academically. One parent remarked, "Greatly appreciate the immediate emails after classes describing the class involvement. Loved the personal touch and details about what was discussed." Many students with IDD report that they love reading these emails and use them to help explain to their family what happened in class. Neurotypical students often help instructors with this summary by emailing them examples of events that the instructor may have missed. The summaries also demonstrate to families that their adult with IDD is capable of learning and showing interest in sophisticated academic subjects.

\section{Course Design}

We have offered a variety of courses on advanced academic topics along with other courses promoting self-sufficiency and independence. To generate course novelty and to accomplish our goal of offering students with IDD a taste of typical college experience, we commission instructors to design courses on topics that may have never been offered to students with IDD but would be popular in modern college curricula. Examples of our previously offered 
courses along with unique opportunities for inclusion in learning and society are outlined in Table 1. Mirroring our neurotypical student preferences, courses focused on music and art were generally more popular than those on science. We found that including the word "science" and "math" in the title led to lower enrollment. Courses on seemingly controversial or challenging topics of religion and psychology, as well as our course on "etiquette" also failed to attract many students. However, we found that combining and remarketing the math and etiquette themes with a fun title "Debutante Ball" led to increased enrollment. In this course students practiced math and etiquette skills to cooperatively plan their own catered banquet with a budget.

Some of our instructors also have experience teaching college courses. For instance, the founder (J.T.P.) teaches upper-level courses in neurogenetics to undergraduate and graduate students. He has found ways to modify material from his courses aimed at neurotypical students for students with IDD. In fact, in doing so, he discovered ways to make complex topics in these hard science subjects more accessible to his neurotypical students. For instance, he minimizes lecturing and offers regular hands-on activities throughout each class. For courses on memory, Alzheimer's and Parkinson's disease, students gloved up to investigate a preserved human brain to note regions important for these conditions. For a course on drug discovery, he had students test a range of drug-like compounds on tiny nematodes to identify ones that reanimate a simple worm model of alcohol withdrawal. To solidify concepts, he has students use colored Play-Doh to craft model neurons and use a 3-foot cardboard box with accessories to model a human eye.

Although some niche courses had low enrollment, they catered to students who were thrilled to learn about a sophisticated specialized topic. For instance, in "Fun with Science: You and Your Genes" an adult with IDD who has been adopted was excited to learn about her genetic heritage as all students learned about the science and ethics behind this new technology. This 
course was recognized by an award in innovative education by the personal genetics company 23andMe. Additional examples of how we have promoted bi-directional learning with reverseinclusion format for STEM, humanities, and self-sufficiency courses are illustrated in Table 3.

\section{Barriers}

Over the past decade, our program has encountered several anticipated (financial and transportation) and unanticipated (family expectations and societal acceptance/buy-in) obstacles. We attempted to address these issues with varying success.

Financial - A few families indicated that the cost of the courses represented a barrier to enrolling or taking more courses. In response, we worked with local agencies including AAAA, ZZZZ, the Autism society of XXXX, and two state agencies, ZZZZ and the ZZZZ. Support was given either in the form of an initial scholarship or partial reimbursement when courses were completed. Interestingly, only five families took advantage of the AAAAA scholarships, and none applied for aide from ZZZZ. When asked, many families stated that they felt the funds should go to others even though they said they would have taken an equivalent scholarship for their neurotypical child's education. Other families indicated that they did not have time to help their student with IDD complete the applications. Some families working with state agencies found ways to reimburse their courses.

Transportation - Most of our students (76\%) enrolled in only one or two courses each year (Figure 1B). Post-course surveys by students with IDD and their families frequently noted that they would like to attend more courses, but transportation was a chief obstacle. The commute to our downtown location was a hassle to some, as was waiting for during class time. Whereas a few male students with IDD used public transportation, parents of female students with IDD were reluctant to allow this option. Carpooling was encouraged, but due to geographic separation of students, this was met with little success. 
During Covid-19, we found that enrollment increased when the transportation barrier was removed with virtual courses. Participation by neurotypical students also increased because they could attend even when travelling or living away from our campus. Starting fall 2021, we have returned to offer in-person courses in parallel to virtual courses for their value in socializing, buying meals at the café, and experiencing a college setting.

Family member expectations -Although one of our goals is to provide adults with IDD the dignity to take courses on mature topics like their neurotypical peers, we found that families were reluctant to sign their students up for courses that seemed controversial, complex, or too mature. Courses that were popular with neurotypical peers such as "Psychology of Science Fiction" and "Fun with Science: Viruses," "Fun with Cultures: World Religions," and "Art of Frida Kahlo" were bypassed. Families were worried their student might get into trouble by talking about these topics inappropriately outside of class.

Nevertheless, we succeeded in filling some courses on mature topics by later remarketing them with more a lighthearted titles and descriptions in subsequent semesters. For instance, a course on business and marketing was reframed with the more palatable "History of Walt Disney," and a course on intimacy and consent was retitled "Romance in the Movies."

Societal Acceptance/Buy-In - Some administrators, university services, and local experts were reluctant to help students with IDD because they did not think they belonged on campus. To gain their buy-in, we reframed our requests, explaining that our program primarily benefitted university students by teaching them about disabilities. Conversely, certain organizations off campus, such as restaurants, and some expert speakers were not interested in helping college students. To surmount this problem, explaining that our program primarily benefits students with 
IDD spurred their involvement. These problems and solutions demonstrate how the reverseinclusion format offers an unexpected strategy to gain wider buy in.

\section{Stakeholder Evaluations}

At the end of each course, we surveyed students with and without IDD for anonymous feedback. Students with IDD answered questions independently or with help from their family. Perspectives on our program from interviews of students with IDD and their parents are below:

Anonymous student with IDD - "I liked how the instructor gave us some basic instructions on how exactly are we supposed to do when doing either Photoshop or draw digitally with existing picture or make your own images. (in Digital Tablet Art course)"

Anonymous student with IDD - "In 2009, we moved to YYYY. That was the best thing because I could go to college at XXXX! There was a science class for adults like me. It was six sessions, one each week. I got to meet XXXX students and professors and experts. I got to learn about different animals and cultures and music and take so many classes. The classes have gotten bigger and there are so many to choose from now. They think we can do anything.

Anonymous parent - "My son really learned a lot in the Mad Science course. I was surprised at how well he assembled the information and wanted to share it. This course was a serious learning experience with advanced education topics geared to his ability."

Questions for neurotypical students probed changed attitudes and experience with students with IDD to compare with pre-course surveys. Sample are presented below.

Anonymous - "I had no previous experience with adults with IDD. Through this course, I came to realize that they are just like me. A lot of us are the same age and have the same interests. This drastically changed how I viewed adults with IDD to socialize and learn.” 
Anonymous - "I had experience with IDD with a family member, volunteering at summer camps and previous courses. But with this “ANONYMOUS_CITY Art” course, I realize that many adults with IDD are extremely creative and can use art to express themselves."

Sample perspectives on our program from long-term instructors are included below:

Lucy - "I have worked in the field of adults with IDD for 10+ years and have yet to encounter a program or mission quite like that of CONT_ED_PROGRAM. I often find that adults with disabilities are given less opportunity for risk taking and intellectual exploration than their neurotypical peers. Most programs and post-secondary opportunities are exclusively oriented toward employment and vocational training. While that is valuable, when I think back to my own college experience, some of the most profound takeaways have very little direct correlation to what I do professionally. The relationships that I made, the sense of independence that I gained, the gift of being able to take classes purely for the sake of learning and expanding my worldview. This is what CONT_ED_PROGRAM offers, a chance for adults with disabilities to participate in the same growth and academic adventure as their classmates and siblings before them. To explore, create and connect."

Joshua - "I appreciate that the CONT_ED_PROGRAM provides a warm and welcoming learning environment for students with IDD to apply the course content to their own lives. While facilitating class discussions I am often in awe of the robust and meaningful ideas the students contribute. In addition to the content being taught, the students also learn from each other's rich and diverse experiences. Compared to other activities for adults with IDD, I feel that our program provides opportunities for students to learn alongside their typical developing peers in addition to building and maintaining lifelong friendships. Students experience the college 
lifestyle by joining their peers each week at a campus café for social time followed by an enriching learning experience held in an on-campus classroom."

\section{DISCUSSION}

For adults with IDD, our program is designed to facilitate inclusion for interpersonal, personal, as well as intellectual development in a college setting. For undergraduate and graduate neurotypical students, the primary and most impactful lesson learned is that people with IDD are more sophisticated multidimensional people than they appear if they are blinded by the disability stereotypes and assumptions. In our classes, traditional and non-traditional students rapidly form relationships that dually transform understanding of people with IDD and encourage a more inclusive society for those with disabilities.

\section{Unique aspects of reverse-inclusion format on university campus}

Our program is distinct from most other PSE programs. While some PSEs foster a few adults with IDD to be included in a limited number of college courses, our program is structured so that students with IDD outnumber neurotypical students, usually 2:1. This format puts many adults with IDD at ease so that they may contribute more uninhibited without worry of comparison to neurotypical college student peers. Likewise, families who help sign up their students with IDD are more assured that the instructor will better tailor the academic material towards their family member with this critical mass of students with IDD.

Most PSE program aimed at students with IDD place primary focus on teaching life and job skills at the expense of exploring wider academic topics at college. This is an important goal to help students with IDD gain employment essential to earn a wage and self-respect and acceptance in general society. Exploring more academics beyond high school years, however, offers the potential benefit of opening a wider variety of satisfying job and volunteer 
opportunities. For instance, in our program an adult with DS showed exceptional interest in science courses that drove her to study outside of class. She was eventually hired as a part-time research assistant in a lab on campus and has maintained employment for 7 years. Another adult with ASD displayed unexpected interest in the "Drug discovery" course by completing extra homework and memorizing which medicines are for what condition. He quit his job bagging groceries, and got a new job at a pharmacy where he can leverage his interest to help customers and his employer. Another adult with DS took our "Spanish language" course and bought himself his first book - a Spanish dictionary that he studied afterward to begin to converse better with his Spanish-speaking co-workers.

By offering a combination of diverse subjects each semester, students could focus or expand on their interests. Our course schedule may be considered brief compared to the format offered by many PSE certificate programs for adults with IDD. However, the à la carte format allows them to sign up for as many courses per semester that fits into their individual or family schedule and budget. A little more than half of the students with IDD took one course per year, while others took two or more (Figure 1B). The modular, once-per-week, six-week format for courses appears to work well with many family schedules. When we offered a twice-per-week version of "Reader's Theater" course, it failed to make. In contrast, our 12-week "Understanding Our Body and Our Rights for Women" course made when offered in synchrony with other sixweek courses. Meeting more than once per week appeared to increase the transportation burden.

The presence of neurotypical college students in the class encourages the instructor to deliver material in a broader, more interesting way than they may have if the class only consisted of adults with IDD. Often adults with IDD surprise the instructor and neurotypical students alike with their level of interest and understanding of material delivered at these higher levels. 
Examples include how students with IDD have provided in-depth discussion from first-hand experience on medical topics in science classes, personal travel experience in foreign culture and history classes, and musical instrument familiarity and performance in music courses. Neurotypical students also contribute valuable content to our classes, such as that relayed from their other college courses, as well as from personal upbringing and community ties. Adults with IDD deserve the dignity to experience unique aspects of university education where they are introduced to fascinating topics at an adult level, and brought to the edge of the unknown alongside their neurotypical peers.

\section{Learning about abilities from adults with disabilities}

Neurotypical students on track for education, medical, and research careers look forward to helping students or patients. Ironically, people with IDD who will need their help, however, are excluded from college by design. This includes $1-3 \%$ of the global population with IDD (Special Olympics, 2021). Thus, many neurotypical students finish college unprepared, not knowing much about people with IDD. Most assume that IDD make college learning impossible. Through direct demonstration, we are teaching neurotypical students about IDD firsthand by having them learn and perform sophisticated educational activities alongside students with IDD.

\section{Program acceptance}

Administrators in our continuing education department were impressed once we demonstrated that students with IDD in our community represent a giant, untapped customer base. More so than their typical customers, students with IDD were more likely to re-enroll in courses over years to learn and to make and maintain friendships. Continuing education programs at colleges need help in designing courses aimed at adult students with IDD. We propose that the formula described here may offer an easy pattern for success. 
People in different roles may start a continuing education program similar to one described here. However, we found that there were benefits of having a tenure-track professor initiate the program (J.T.P.). A tenured professor may have access to reserve rooms, such as science labs, that an outside instructor or non-tenure track professor may not. Professors may more easily recruit peer professors, grad students, and postdocs to serve as guest experts. In turn, college professors may use the program as an exceptional outreach project in education and science grants (e.g. National Science Foundation, Beckman Foundation, and HHMI). If program founders have family members with IDD, then they may also gain additional assistance from their support organizations by providing a more compelling personal account to found and grow the program when communicating to people unfamiliar with IDD.

\section{Additional benefits}

Our continuing education program has demonstrated several additional benefits in its decade of operation. Many students with IDD have used our reverse-inclusion program as a stepping stone for themselves (or oftentimes, their family) to gain experience and confidence before they enroll in other PSE programs. Many have gone on to PSE programs including PSE_PROGAM at XXXX Community College, YYYY at XXXX, and Mason LIFE PSE program at George Mason University. Yet another student with autism had completed a computer degree online at DeVry University, but joined our program to overcome his social anxiety before planning to take advanced programming courses in-person with neurotypical students. These examples show how our program may bolster other inclusive PSE programs. Although we are not offering a full college experience, the opportunity we provide to socialize and learn for a few hours a week in the heart of campus allows them to encounter a vibrant atmosphere of typical college students who are likewise socializing and learning. The 
continuing education format allows most students to continue our program for several years. This longer duration may provide them with accumulative memories of socializing and learning at college that resemble those of typical college students. Students often buy university notebooks and clothing to display their university spirit which gains them extra attention and acceptance from their family and community.

Our program opened novel relationships between students with IDD and guest experts. Almost all invited experts had no experience with people with IDD, but they reported being impressed with the level of interest and participation by students with IDD after their visit. Guest experts often volunteered to appear without compensation, and found the opportunity rewarding.

Our program presents a degree of inclusive organization not found in most other PSE programs for adults with IDD. The staff of CONT_ED_PROGRAM advertises our program and handles sales of class seats alongside their courses aimed at the general public. An ultimate goal for our program is to encourage students with IDD to try out the wide range of continuing education classes aimed at neurotypical peers in the general public by advertising our reverseinclusion courses side-by-side. This is in part why we chose to share the name of our continuing education program rather than something different. To the best of our knowledge, this is rare in PSE for at adult students with IDD. As inclusion at the K-12 education levels reaches higher acceptance, more students and families may consider these new opportunities for inclusion.

Our program ties learning and socializing of diverse groups together, many of which have never spent time with adults with IDD, nor considered what they are capable of holding interest in or learning. We have been able to change minds and boost expectations of guests, neurotypical students, and even instructors, families and the students with IDD themselves.

\section{Future directions}


Reverse inclusion represents only one vision and not the ultimate vision for inclusion. Many students with IDD want to be included in college, and currently there are over 4000 students being served by the 308 programs in the U.S. (Think College, 2021). During 2016-2018, in parallel to the program described above, we also offered students with IDD the opportunity to join any of the continuing education courses offered to the general public in CONT_ED_PROGRAM. They would be paired with a neurotypical student who could provide assistance in class only as needed. Several students with IDD self-selected a range of courses (e.g. Swing Dancing, Hip Hop Dancing, Native American Culture, Oil Painting). Students and their families reported a positive experience, especially the opportunity to choose among a wider variety of course topics. However, all families also reported that they remained skeptical that the instructor and the neurotypical class peers were committed to engaging their adult with IDD to the same level as those in our reverse-inclusion program. Thus, most families associated with our program remain hesitant to participate in full inclusion, and instead requested expansion of our reverse-inclusion courses. From our experience, the number and ability range of adults with IDD who would be interested in continuing education with reverse-inclusion format greatly exceeds the subset of adults with IDD who are interested in straightforward inclusion. However, the existence of a reverse-inclusion program on a campus does not appear to deter the development of alternate inclusive programs because, YYYYY, a distinct 1.5-year PSE program for 15 adults with IDD per year was successfully launched in parallel to our program on our campus in 2018.

\section{Implications \& recommendations}

This type of program can serve as a feeder to 1-4-year PSE programs because it prepares students for learning situations with neurotypical students and familiarizes them with the college campus. They can develop their academic identities in advance of more rigorous course requirements which aligns with 
research findings from inclusive PSE program administrators who note that students with IDD require more time on campus to adjust to college life (Shetron, 2020).

We feel that the decade-tested formula presented here to grow a reverse-inclusion PSE program may be readily replicated at most any college. This would be especially feasible for those that already have a continuing education program that is searching for ways to extend their customer base with a steady supply of learners with free time and financial support. Adding a PSE program such as this that serves students with IDD not only fulfills a need for PSE opportunities for students with IDD, but also provides financial stability to the continuing education program, as well as valuable goodwill with the community.

\section{REFERENCES}

Ditchman, N., Werner, S., Kosyluk, K., Jones, N., Elg, B., \& Corrigan, P. W. (2013). Stigma and intellectual disability: Potential application of mental illness research. Rehabilitation Psychology, 58(2), 206-216. https://doi.org/10.1037/a0032466

Folk, E. D., Yamamoto, K. K., \& Stodden, R. A. (2012). Implementing inclusion and collaborative teaming in a model program of postsecondary education for young adults with intellectual disabilities. Journal of Policy and Practice in Intellectual Disabilities, 9(4), 257-269. https://doi.org/10.5604/01.3001.0012.7544

Giroux, H. A. (2012). Can democratic education survive in a neoliberal society. Crisis and Commonwealth: Marcuse, Marx, McLaren, 137-152.

Grigal, M., Hart, D., Papay, C., Smith, F., Domin, D., \& Lazo, R. (2020). Executive summary of the year four annual report of the TPSID Model Demonstration Projects (2018-2019) (Issue No. 26). Think College Fast Facts, Institute of Community Inclusion. https://hinkcollege.net/sites/default/files/files/resources/FF26_Executive_Summary_Yea $\underline{\text { r4 Annual Report.pdf }}$ 
Higher Education Opportunity Act of 2008, Pub. L. No. 110-315 § 122 STAT. 3078 (2008).

Karmiloff-Smith, A. (2009). Nativism versus neuroconstructivism: Rethinking the study of developmental disorders. Developmental psychology, 45(1), 56-64. https://doi.org/ doi: $\underline{10.1037 / \mathrm{a} 0014506}$

Loeb, S., Dynarski, S., McFarland, D., Morris, P., Reardon, S., \& Reber, S. (2017). Descriptive Analsyis in Education: A Guide for Researchers. NCEE 2017-4023. National Center for Education Evaluation and Regional Assistance. https://files.eric.ed.gov/fulltext/ED573325.pdf

Qian, X., Johnson, D. R., Smith, F. A., \& Papay, C. K. (2018). Predictors associated with paid employment status of community and technical college students with intellectual disability. American Journal on Intellectual and Developmental Disabilities, 123(4), 329-343. https://doi.org/10.1352/1944-7558-123.4.329 Shetron, 2020

Special Olympics (2021). What is Intellectual Disability?

https://www.specialolympics.org/about/intellectual-disabilities/what-is-intellectual$\underline{\text { disability?locale }=\mathrm{en}}$

Taşçı, G., \& Titrek, O. (2019). Evaluation of lifelong learning centers in higher education: a sustainable leadership perspective. Sustainability, 12(1), 1-1.

Think College (2021). Programs. https://thinkcollege.net/college-search

Toffler, A. (1970). Future shock. New York: Random House.

Wolfensberger, W. (1998). A brief introduction to social role valorization: A high-order concept for addressing the plight of societally devalued people, and for structuring human services. Training Institute for Human Service Planning, Leadership \& Change Agency.

\begin{tabular}{|l|c|c|c|c|}
\hline Course name & H & STEM & PD & Enrollment \\
\hline Fall 2010 - Fun with Science: Our senses & & $\checkmark$ & & 14 \\
\hline Summer 2011 - Fun with Science: Drugs and alcohol & & $\checkmark$ & & 14 \\
\hline
\end{tabular}




\begin{tabular}{|c|c|c|c|c|}
\hline Fall 2011 - Fun with Science: Parkinson's disease & & $\checkmark$ & & 14 \\
\hline Fall 2012 - Fun with Science: Amazing animals! & & $\checkmark$ & & 14 \\
\hline Fun with Culture: Japanese culture & $\checkmark$ & & & 14 \\
\hline Spring 2012 - Fun with Culture: Spain culture & $\checkmark$ & & & 14 \\
\hline Fun with Math: You and your money & & $\checkmark$ & & 10 \\
\hline Summer 2012- Fun with Science: Drug discovery & & $\checkmark$ & & 12 \\
\hline Spring 2013 - Building Language Arts Skills & $\checkmark$ & & & 12 \\
\hline Math for Daily Living & & $\checkmark$ & & 10 \\
\hline Building Writing Skills & $\checkmark$ & & $\checkmark$ & 10 \\
\hline Spring 2014 - Introduction to Spanish for Adults with IDDs & $\checkmark$ & & & 12 \\
\hline Fun with Math for Adults with Intellectual Disabilities & & $\checkmark$ & & 10 \\
\hline Art Culture: Impressionism for Adults with Intellectual Disabilities & $\checkmark$ & & & 14 \\
\hline Summer 2014 - Reintroduction to Reading for Adults with IDDs & $\checkmark$ & & $\checkmark$ & 10 \\
\hline Building Writing Skills for Adults with IDDs & $\checkmark$ & & $\checkmark$ & 8 \\
\hline Fun with Cultures: Jazz for Adults with IDDs & $\checkmark$ & & & 10 \\
\hline Fun with Cultures: African Adventures for Adults with IDDs & $\checkmark$ & & & 12 \\
\hline Fall 2014 - Readers Theater Aimed at Adults with IDDs & $\checkmark$ & & $\checkmark$ & 13 \\
\hline Math for Daily Living Aimed at Adults with IDDs & & $\checkmark$ & & $\mathrm{X}$ \\
\hline Fun with Cultures: History of Rock n' Roll Aimed at Adults with IDDs & $\checkmark$ & & & 14 \\
\hline Personal Safety for Adults with IDDs Part I: Everyday safety & & & $\checkmark$ & 14 \\
\hline Personal Safety for Adults with IDDs Part II: Healthy relations & & & $\checkmark$ & 14 \\
\hline Your Texas Government Aimed at Adults with IDDs & $\checkmark$ & & & 13 \\
\hline Spring 2015 - Jumpstart Reading & $\checkmark$ & & $\checkmark$ & 10 \\
\hline Happy Habits: Psychology of Happiness & & $\checkmark$ & & 8 \\
\hline Fun with Cultures: Archeology of Ancient Americas & & $\checkmark$ & & 12 \\
\hline Fun with Cultures: Music in World Cultures & $\checkmark$ & & & 14 \\
\hline Etiquette Excellence & $\checkmark$ & & $\checkmark$ & $\mathbf{x}$ \\
\hline Worth A Thousand Words: Short Story Writing & $\checkmark$ & & & 12 \\
\hline Summer 2015 - Fun with Science: Building Better Brains & $\checkmark$ & & & 14 \\
\hline Reader's theater & $\checkmark$ & & $\checkmark$ & 12 \\
\hline Fun with Cultures: Film Studies & $\checkmark$ & & & 12 \\
\hline Debutante Ball & $\checkmark$ & & $\checkmark$ & 12 \\
\hline Fall 2015 - Fun with Cultures: Ciao, Italy! & $\checkmark$ & & & 14 \\
\hline Fun with Cultures: The Hype on Hip Hop & $\checkmark$ & & & 13 \\
\hline Self Improvement: Life-Pro Tips & & & $\checkmark$ & 11 \\
\hline Self Improvement: Healthy Relationships & & & $\checkmark$ & 14 \\
\hline Fun with Science: Our Senses & & $\checkmark$ & & 14 \\
\hline Fun with Science: Chemistry creativity & & $\checkmark$ & & 14 \\
\hline Spring 2016 - Reader's Theater & $\checkmark$ & & $\checkmark$ & 9 \\
\hline Slam Dunk! Basketball Basics & $\checkmark$ & & & 14 \\
\hline "Mais, Oui!" French for Everyone & $\checkmark$ & & & 12 \\
\hline Diverse Drums & $\checkmark$ & & & 14 \\
\hline Creative Photography & $\checkmark$ & & & 12 \\
\hline Your move! Fun with Board Games & $\checkmark$ & & & 12 \\
\hline Psychology of Science Fiction & & $\checkmark$ & & $\mathbf{x}$ \\
\hline Summer 2016 - Stop Motion Animation Production & $\checkmark$ & $\checkmark$ & & 10 \\
\hline Mesoamerica! Ancient Art and Culture & $\checkmark$ & & & 12 \\
\hline History of Country Music & $\checkmark$ & & & 14 \\
\hline
\end{tabular}




\begin{tabular}{|c|c|c|c|c|}
\hline Fun With Cultures: Film Studies & $\checkmark$ & & & 13 \\
\hline Fun With Cultures: The Fantastic World of French! & $\checkmark$ & & & 12 \\
\hline Fall 2016 - Reader's Theater & $\checkmark$ & & & 8 \\
\hline It's my turn! Fun with Board Games & $\checkmark$ & & & 10 \\
\hline Fun With Cultures: Let's Celebrate Spanish! & $\checkmark$ & & & 11 \\
\hline Fun With Cultures: Introduction to World Religions & $\checkmark$ & & & $\mathrm{X}$ \\
\hline Fun With Science: Researching Alzheimer's Disease & & $\checkmark$ & & 10 \\
\hline It's My Party (And I'Il Dance If I Want To) & $\checkmark$ & & $\checkmark$ & 14 \\
\hline Fun With Science: Our Solar System & & $\checkmark$ & & 12 \\
\hline Spring 2017 - Fun with Rastafarian Cultures: A look into Reggae Music & $\checkmark$ & & & $\mathbf{X}$ \\
\hline Fun with Culture: Pop Rocks! Pop Art and Art History & $\checkmark$ & & & 13 \\
\hline Dinosaurs: Digging up the past & & $\checkmark$ & & 12 \\
\hline Putting Your Best Face Forward & & & $\checkmark$ & 14 \\
\hline Musical Performance: Phantom of the Opera & $\checkmark$ & & & 13 \\
\hline Drawn Together: The Written Art of Comic Books and Graphic Novels & $\checkmark$ & & & 14 \\
\hline Fun with Science: You and Your Genes & & $\checkmark$ & & 7 \\
\hline Summer 2017 -Culture of Japan & $\checkmark$ & & & 12 \\
\hline Austin Live Music & $\checkmark$ & & & 12 \\
\hline Amazing Animals & & $\checkmark$ & & 13 \\
\hline Mythology Through the Ages & $\checkmark$ & & & 12 \\
\hline Fall 2017 - Reader's Theater & $\checkmark$ & & $\checkmark$ & 9 \\
\hline Austin Art & $\checkmark$ & & & 12 \\
\hline Personal Safety for Adults with Disabilities & & & $\checkmark$ & 14 \\
\hline Fun with Games: Contest of Champions & $\checkmark$ & & & 12 \\
\hline Musical Performance: The King and I & $\checkmark$ & & & 13 \\
\hline Fun with Cultures: Invitation to India & $\checkmark$ & & & 14 \\
\hline Spring 2018 - Fun with Music: Great American Song Writers & $\checkmark$ & & & 13 \\
\hline Magical Tour with Disney & $\checkmark$ & & & 14 \\
\hline Pandas, Noodles, and More: A Chinese Adventure & $\checkmark$ & & & 14 \\
\hline Fun with Culture: Beginning Spanish & $\checkmark$ & & & 12 \\
\hline Creative Photography & $\checkmark$ & & & 13 \\
\hline Night at the Movies: Oscar awards!! & $\checkmark$ & & & 14 \\
\hline Summer 2018 - Art of Ancient Egypt & $\checkmark$ & & & 12 \\
\hline Mad Science & & $\checkmark$ & & 13 \\
\hline Volunteer Opportunities & & & $\checkmark$ & 12 \\
\hline Fall 2018 - Mindfulness Matters & & & $\checkmark$ & 12 \\
\hline Fun with Science: Journeys in Marine Life & & $\checkmark$ & & 14 \\
\hline Get to Know Austin & $\checkmark$ & & & 12 \\
\hline Fun with Cultures: Global Culinary Adventure & $\checkmark$ & & & 14 \\
\hline Fun with Music: You Can Ukulele! & $\checkmark$ & & & 12 \\
\hline Music Journalism for Everyone & $\checkmark$ & & & 14 \\
\hline Spring 2019 - Stop Motion Animation Production & $\checkmark$ & $\checkmark$ & & 13 \\
\hline Mona Lisa, Smile! Renaissance Art & $\checkmark$ & & & 12 \\
\hline Musical Performance: Fiddler on the Roof & $\checkmark$ & & & 14 \\
\hline The Facts and Fictions of Onscreen Romance & & & $\checkmark$ & 14 \\
\hline Wonders of Wizardry & $\checkmark$ & $\checkmark$ & & 14 \\
\hline How Laughing is Good For You & & $\checkmark$ & $\checkmark$ & 10 \\
\hline Summer 2019 - Fun with culture: Small Screen - Big Picture & $\checkmark$ & & & 13 \\
\hline Fun with Science: Journeys in Marine Life & & $\checkmark$ & & 12 \\
\hline
\end{tabular}




\begin{tabular}{|c|c|c|c|c|}
\hline Fun with culture: Gladiators of Art in Ancient Rome & $\checkmark$ & & & 9 \\
\hline Musical Performance: The Little Mermaid & $\checkmark$ & & & 14 \\
\hline Fall 2019 - Best of Austin from the Eyes of Adults with IDDs & $\checkmark$ & & $\checkmark$ & 12 \\
\hline Understanding Our Bodies \& Our Rights for Women with IDDs (12 weeks) & & & $\checkmark$ & 7 \\
\hline Fun with South Congress Avenue History & $\checkmark$ & & & 12 \\
\hline Fun with Games: Building, Diving and Exploring & $\checkmark$ & & & 12 \\
\hline Fun with Digital Tablet Art aimed at Adults with IDD's & $\checkmark$ & $\checkmark$ & & 10 \\
\hline Musical Appreciation Dear Evan Hansen & $\checkmark$ & & & 14 \\
\hline Spring 2020 - Fun with Cultures: Celebrations and Fun in India & $\checkmark$ & & & 13 \\
\hline Fun with Art: Focus on Frida Kahlo & $\checkmark$ & & & $\mathrm{X}$ \\
\hline Fun with Science: Crime Scene Investigations & & $\checkmark$ & & 13 \\
\hline Ballet Appreciation: A Midsummer Night's Dream & $\checkmark$ & & & 13 \\
\hline Show me the money! & & $\checkmark$ & $\checkmark$ & 11 \\
\hline Creative Photography & $\checkmark$ & & & 12 \\
\hline
\end{tabular}

Table 1. Chronical list of courses aimed at adults with IDDs at The University of Texas at Austin. Course names with corresponding subtopic (H: humanities; STEM: science, technology, engineering, or math; and PD: personal development). Enrollment of adults with IDDs is listed unless a course failed to make due to fewer than 6 adults with IDDs registering $(X)$. Shading helps distinguish courses offered in successive years. All but one were 6 weeks.

\begin{tabular}{|l|l|l|l|l|}
\hline & Phase I & Phase II & Phase III & Phase IV \\
\hline Participants & 2010-2011 & 2012 & 2012-2013 & 2014-2020 \\
\hline $\begin{array}{l}\text { Students with } \\
\text { IDD }\end{array}$ & $\begin{array}{l}\text { Typical class had 14 } \\
\text { students with DS } \\
\text { (18-41 yrs old; } \\
\text { mean 25; 50:50 } \\
\text { M:F); reading } \\
\text { ability (none-6th } \\
\text { grade level) }\end{array}$ & $\begin{array}{l}\text { Typical class had 8 } \\
\text { students with DS and 5 } \\
\text { students with ASD or } \\
\text { undefined IDD; } \\
\text { students from assisted } \\
\text { living centers; 60:40 } \\
\text { M:F }\end{array}$ & $\begin{array}{l}\text { Typical class had 8 } \\
\text { students with ASD, and 4 } \\
\text { students with DS, and 2 } \\
\text { students with IDD } \\
\text { undefined origin; 60:40 } \\
\text { M:F }\end{array}$ & $\begin{array}{l}\text { Typical class had 8 students } \\
\text { with ASD, and 4 students } \\
\text { with DS, and 2 students } \\
\text { with IDD undefined origin; } \\
60: 40 \text { M:F }\end{array}$ \\
\hline $\begin{array}{l}\text { Neurotypical } \\
\text { students }\end{array}$ & $\begin{array}{l}\text { Pre-med and } \\
\text { neuroscience major } \\
\text { college students }\end{array}$ & $\begin{array}{l}\text { Pre-med and } \\
\text { neuroscience major } \\
\text { college students }\end{array}$ & $\begin{array}{l}\text { Pre-med, neuroscience, } \\
\text { and education major } \\
\text { college students }\end{array}$ & $\begin{array}{l}\text { Pre-med, neuroscience, } \\
\text { and education major } \\
\text { college students; university } \\
\text { staff }\end{array}$ \\
\hline Instructors & Professor & $\begin{array}{l}\text { Professor, transition } \\
\text { specialist }\end{array}$ & $\begin{array}{l}\text { Professor, transition } \\
\text { specialist, special ed } \\
\text { teachers }\end{array}$ & $\begin{array}{l}\text { Professors, transition } \\
\text { specialist, special ed } \\
\text { teachers, undergrad \& grad } \\
\text { students }\end{array}$ \\
\hline Guest experts & Professors & $\begin{array}{l}\text { Professors, musicians } \\
\text { \& dancers }\end{array}$ & $\begin{array}{l}\text { Professors, musicians, } \\
\text { dancers \& artisans }\end{array}$ & $\begin{array}{l}\text { Professors, artisans, } \\
\text { musicians, dancers \& } \\
\text { outside experts }\end{array}$ \\
\hline Administration & Founder & Founder & $\begin{array}{l}\text { Contin_Ed_program \& } \\
\text { Program Coordinator }\end{array}$ & $\begin{array}{l}\text { Contin_Ed_program \& } \\
\text { Program Coordinator }\end{array}$ \\
\hline
\end{tabular}

Table 2. Progression of continuing education program. Typical class composition across phases of growth.

\begin{tabular}{|l|l|l|l|l|}
\hline $\begin{array}{l}\text { Category \& } \\
\text { Course title }\end{array}$ & Instructor & Learning Goals & $\begin{array}{l}\text { Guest Experts and hands-on } \\
\text { activities }\end{array}$ & Bi-directional learning \\
\hline
\end{tabular}




\begin{tabular}{|c|c|c|c|c|}
\hline $\begin{array}{l}\text { Science: } \\
\text { Fun with } \\
\text { Science: } \\
\text { Crime Scene } \\
\text { Investigation }\end{array}$ & $\begin{array}{l}\text { Undergrad } \\
\text { student } \\
\text { majoring in } \\
\text { Neuroscience }\end{array}$ & $\begin{array}{l}\text { Explore common } \\
\text { criminology themes, } \\
\text { popular crime scene } \\
\text { investigation } \\
\text { techniques, and } \\
\text { careers in forensic } \\
\text { science }\end{array}$ & $\begin{array}{l}\text { - Forensic psychologist } \\
\text { discussed job } \\
\text { - Performed mock blood } \\
\text { splatter analysis } \\
\text { - Explored criminology themes, } \\
\text { popular crime scene } \\
\text { investigation techniques, and } \\
\text { careers in forensic science }\end{array}$ & $\begin{array}{l}\text { - Students with IDDs } \\
\text { demonstrated advanced } \\
\text { knowledge of serial killers and } \\
\text { forensic entomology by } \\
\text { identifying common crime } \\
\text { scene insects that } \\
\text { neurotypical students were } \\
\text { unfamiliar }\end{array}$ \\
\hline $\begin{array}{l}\text { Science: } \\
\text { Building } \\
\text { Better Brains }\end{array}$ & $\begin{array}{l}\text { Professor in } \\
\text { Neuroscience } \\
\text { Dept }\end{array}$ & $\begin{array}{l}\text { How memories form } \\
\text { and are retrieved; } \\
\text { how different } \\
\text { mnemonic devices } \\
\text { work in relation }\end{array}$ & $\begin{array}{l}\text { - Learn how memory works } \\
\text { - Practiced strategies to } \\
\text { improve memory } \\
\text { - Neuroscientist who } \\
\text { researches memory } \\
\text { - Expert card player taught } \\
\text { how to memorize sequences of } \\
\text { cards }\end{array}$ & $\begin{array}{l}\text { - Some students with ASD } \\
\text { could remember twice as } \\
\text { much info as neurotypical } \\
\text { students using synesthesia, } \\
\text { and some students with IDD } \\
\text { showed that they could } \\
\text { transiently double their lower } \\
\text { memory capacity }\end{array}$ \\
\hline $\begin{array}{l}\text { Humanities: } \\
\text { Fun with } \\
\text { Cultures: } \\
\text { Chinese } \\
\text { Culture }\end{array}$ & $\begin{array}{l}\text { Undergrad } \\
\text { student } \\
\text { majoring in } \\
\text { Neuroscience }\end{array}$ & $\begin{array}{l}\text { Aspects about } \\
\text { everyday life in } \\
\text { China and artistic } \\
\text { culture including: } \\
\text { writing, language, } \\
\text { and foods. }\end{array}$ & $\begin{array}{l}\text { - Chinese students taught } \\
\text { language \& writing lessons } \\
\text { - Chinese artisans shared foods } \\
\text { and recipes } \\
\text { - Chinese musicians } \\
\text { demonstrated flute }\end{array}$ & $\begin{array}{l}\text { - Many students with IDD } \\
\text { grasped conversational } \\
\text { Mandarin phrases and } \\
\text { complex Chinese characters } \\
\text { more efficiently than } \\
\text { neurotypical students. }\end{array}$ \\
\hline $\begin{array}{l}\text { Humanities: } \\
\text { Our State } \\
\text { Government }\end{array}$ & $\begin{array}{l}\text { Undergrad } \\
\text { majoring in } \\
\text { Special } \\
\text { education }\end{array}$ & $\begin{array}{l}\text { How laws are made; } \\
\text { how to contact your } \\
\text { representative with } \\
\text { persuasive } \\
\text { arguments and } \\
\text { letters }\end{array}$ & $\begin{array}{l}\text { - State representatives met } \\
\text { with students in class and at } \\
\text { capital building to discuss their } \\
\text { concerns } \\
\text { - Met with lawyer to address } \\
\text { concerns on guardianship }\end{array}$ & $\begin{array}{l}\text { - Students with and without } \\
\text { IDDs learned about their } \\
\text { distinct legal concerns (e.g. } \\
\text { guardianship \& ABLE savings } \\
\text { accounts vs rent assistance \& } \\
\text { college savings) }\end{array}$ \\
\hline $\begin{array}{l}\text { Independent } \\
\text { living: Fact } \\
\text { and Fiction of } \\
\text { Onscreen } \\
\text { Romance } \\
\text { Thanks }\end{array}$ & $\begin{array}{l}\text { Transition } \\
\text { specialist }\end{array}$ & $\begin{array}{l}\text { To recognize } \\
\text { appropriate vs } \\
\text { inappropriate } \\
\text { relationship issues } \\
\text { and expectations in } \\
\text { movies and in real } \\
\text { life }\end{array}$ & $\begin{array}{l}\text { - Relationship counselor that } \\
\text { specializes in working with } \\
\text { adults with IDD } \\
\text { - Role played awkward social } \\
\text { interactions and discuss ways } \\
\text { to improve } \\
\text { - Study video clips of popular } \\
\text { but inappropriate romantic } \\
\text { scenes in movies }\end{array}$ & $\begin{array}{l}\text { - Neurotypical students } \\
\text { shared example issues in } \\
\text { dating, while students with } \\
\text { IDD revealed their examples } \\
\text { of boundaries in friendships } \\
\text { and occasional dating } \\
\text { - Students with IDD often had } \\
\text { longer relationships than the } \\
\text { neurotypical students so we } \\
\text { able to speak to the } \\
\text { experience of committed } \\
\text { dating in a deeper way }\end{array}$ \\
\hline $\begin{array}{l}\text { Independent } \\
\text { living: Put } \\
\text { Your Best } \\
\text { Face Forward: } \\
\text { Interviewing } \\
\text { and } \\
\text { Auditioning }\end{array}$ & $\begin{array}{l}\text { Doctoral } \\
\text { student in } \\
\text { Developmental } \\
\text { Education with } \\
\text { a background in } \\
\text { theatre and } \\
\text { music }\end{array}$ & $\begin{array}{l}\text { To present self in a } \\
\text { positive/engaged } \\
\text { manner for } \\
\text { interviews and } \\
\text { auditions, and to } \\
\text { present experiences } \\
\text { in a well-designed } \\
\text { resume }\end{array}$ & $\begin{array}{l}\text { - Practiced interviews and } \\
\text { auditions in class with each } \\
\text { other and instructor } \\
\text { - Worked in groups to } \\
\text { recognize unique strengths } \\
\text { - Refined resumes to highlight } \\
\text { strengths and aim towards goal } \\
\text { job or production }\end{array}$ & $\begin{array}{l}\text { - Students learned to present } \\
\text { themselves physically and on } \\
\text { paper in a positive format. } \\
\text { Students practiced interviews } \\
\text { on each other, practiced } \\
\text { assuming positive physical } \\
\text { stances, and engaging } \\
\text { conversation techniques. }\end{array}$ \\
\hline
\end{tabular}

Table 3. Example course content from reverse-inclusion PSE courses. 


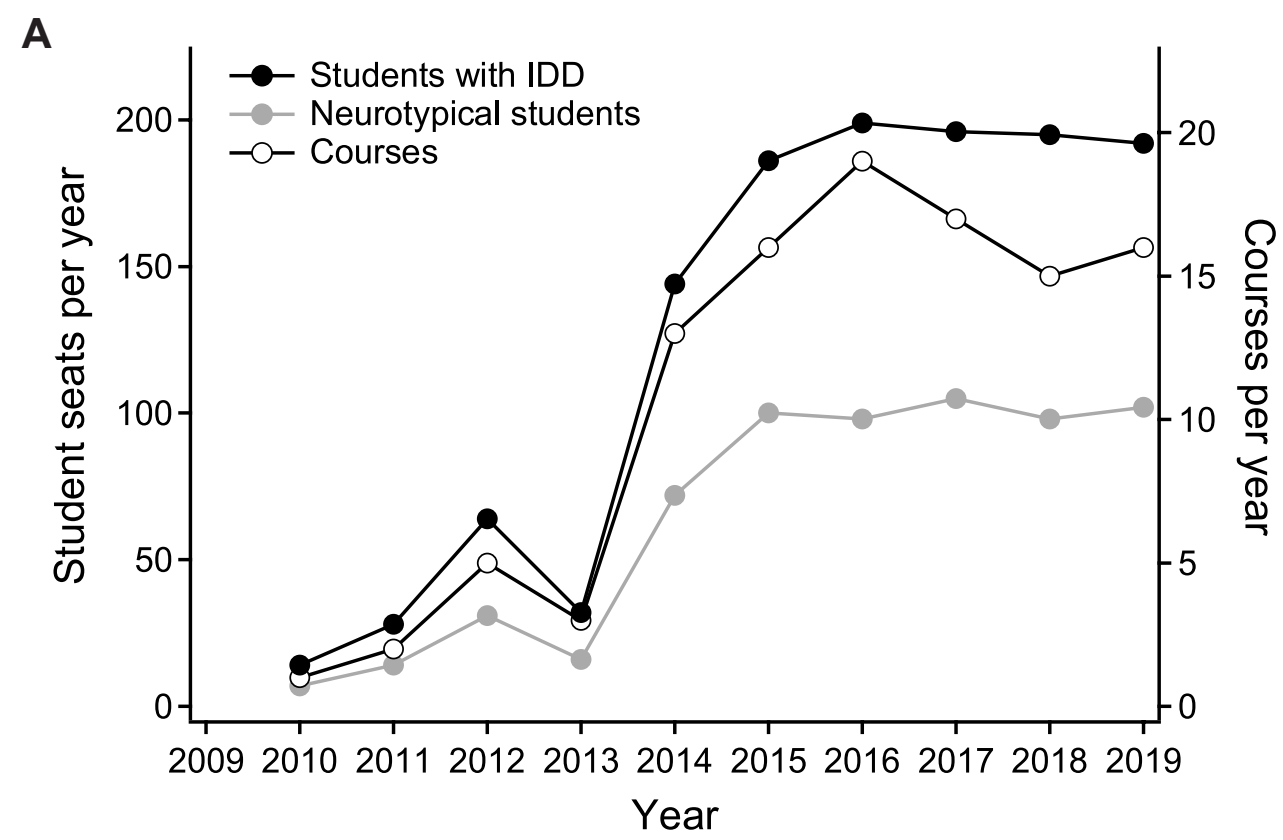

B

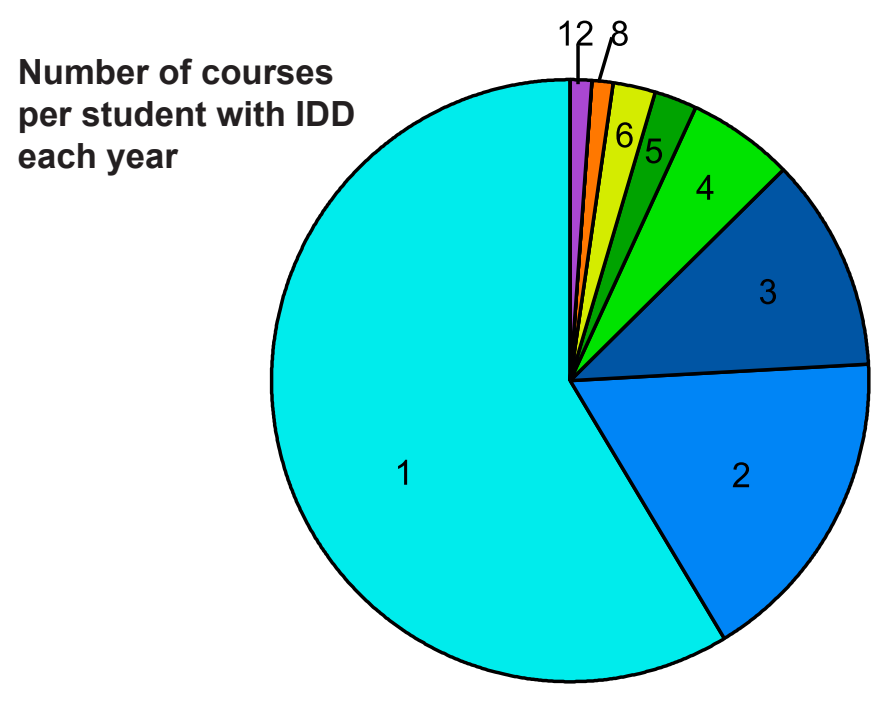

Figure 1. XXXXXXXXXXXXXXX program statistics. A. Growth in student enrollment and courses. The number of seats steadily increased over the decade along with the number of courses. Seats and courses declined slightly in 2013 when the Program Coordinator was busy with obtaining tenure, but growth resumed with administrative assistance from the $X X X X X X X X X X X X X X$ continuing education department at The University of $X X X X X X X X X$. B. Pie chart displaying the normalized number of courses taken per individual student with IDD from 2014 onward. Students with IDD divided into two general groups. A little more than half took only one course each year, while the other students took two or more courses each year. One student took 12 courses each year. 
A Today we learned about how doctors and scientists are attempting to prevent, stop or slow Alzheimer's disease. We also reviewed main concepts about Alzheimer's disease and what we have learned in class so far. Please complete this homework by yourself and with the help of someone else. Write text or draw pictures to complete the answers. We will discuss your homework together in our next class.

1. Which parts of the brain die first in Alzheimer's disease? Please circle the damaged area(s) in the picture. If you remember the name of the brain region, write that too.

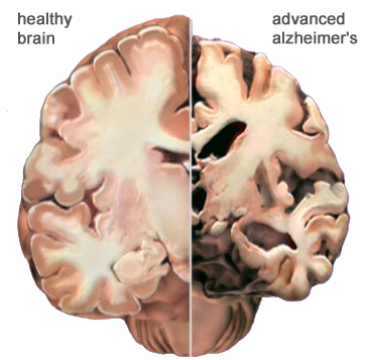

2. In class we made a model of a healthy neuron and a neuron in Alzheimer's disease. See the attached diagram. Please label the molecules using slides.

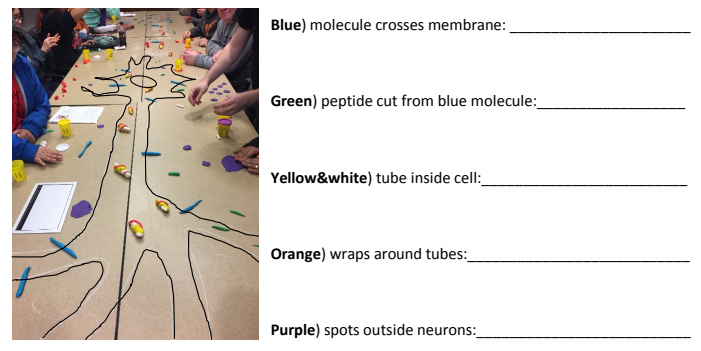

C

Homework for our next class - students may pick one or more of the options Artwork - this activity includes designing your own drawing or painting inspired by a character, or characters, from the Disney movie that we will study in our next class. Prepare to share your visual artwork with the class.

Costume - get a costume ready to wear to our next class based on a character, or characters, from the Disney movie that we will study in our next class. Prepare to show and present your costume with the class.

Song - compose an original song, or find a song that you are familiar with, from the Disney movie that we will study in our next class. Prepare to sing and/or play your song with the class.

Dance - make up a dance or dance moves inspired by the music from the Disney movie that we will study in our next class. Prepare to show us your dance.

Create a Character - create your own, unique character inspired by the Disney movie that we will study in our next class. Prepare to share your character with the class.
B

Today we were introduced general aspects of religion in Japan, as well as common foods: tea and sweetened red-bean, and we continued learning Japanese vowels.

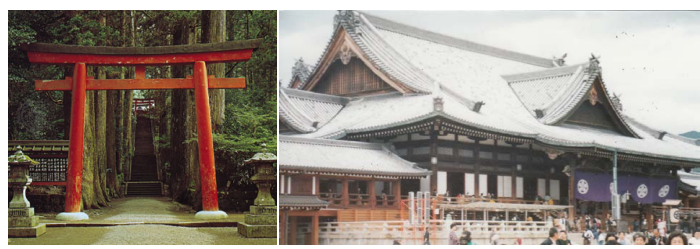

1. Photos above show structures from Shinto or Buddhist relgions?

Left:

Right:

2. People who get married in Japan consider which type of religion?

3. People consider which religion when they have a funeral?

4. Do people in Japan usually attend church every week?

5. What are some differences between different types of Japanese teas? Which one did you like to drink?

6. What are ema for? What did you write on your ema? You can write on back...

\begin{tabular}{|c|c|}
\hline 1. My boss is SUCH a jerk!! & 1. $\mathrm{YES} / \mathrm{NO}$ \\
\hline $\begin{array}{l}\text { 2. Saw the new Toy Story movie! } \\
\text { Two thumbs up! }\end{array}$ & 2. YES/NO \\
\hline $\begin{array}{l}\text { 3. Going to eat dinner at } \\
\text { California Pizza Kitchen tonight, } \\
\text { 11/7, at } 7 \mathrm{pm} \text { at Barton Creek } \\
\text { Mall! }\end{array}$ & 3. $\mathrm{YES} / \mathrm{NO}$ \\
\hline $\begin{array}{l}\text { 4. My doctor prescribed me a } \\
\text { new medication for my } \\
\text { seizures. }\end{array}$ & 4. YES/NO \\
\hline 5. I got a new job! Woohoo! & 5. YES/NO \\
\hline $\begin{array}{l}\text { 6. I have } \$ 356 \text { dollars in my Bank } \\
\text { of America checking account!! }\end{array}$ & 6. YES/NO \\
\hline 7. Excited for Thanksgiving! & 7. YES/NO \\
\hline $\begin{array}{l}\text { 8. The new Taylor Swift is } \\
\text { AMAZING! }\end{array}$ & 8. YES/NO \\
\hline $\begin{array}{l}\text { 9. I believe in God and everyone } \\
\text { who doesn't is in big trouble! }\end{array}$ & 9. $\mathrm{YES} / \mathrm{NO}$ \\
\hline $\begin{array}{l}\text { 10. Fun time with my church grour } \\
\text { today! Such nice people! }\end{array}$ & 10.YES/NO \\
\hline
\end{tabular}

appropriate to send to a fiend:

My boss is SUCH a jerk!!

1. YES/NO

YES/NO

YES/NO

California Pizza Kitchen tonight,

$11 / 7$, at $7 \mathrm{pm}$ at Barton Creek

My doctor prescribed me a

YES/NO

YES/NO

7. YES/NO

today! Such nice people!

10.YES/NO

Figure 2. Example homework assignments. A. Japanese culture course. B. Alzheimer's disease course. C. Magical tour with Disney. B. Healthy relationship course. 


\section{Plain language summary}

People with intellectual and developmental disabilities (IDD) experience limited opportunities for lifelong educational opportunities in socially valued places with their peers. College is a place where many young adults go to learn new things, sample prospective careers, and learn more about themselves and the world around them. Our Reverse Inclusion program for students with IDD allows students with and without IDD to (1) continue to learn new things, (2) explore careers by meeting guests with diverse jobs, and (3) gain a better understanding of themselves and the world around them. Students with diverse circumstances can participate because typical barriers are removed to continuing education such as long-term commitment, high costs, and gate-keeping entrance exams and requirements. In this article we describe the design and implementation of one such reverse inclusion program so that others may see its unique value and replicate it at their institution of higher education. In doing so, more equitable access to higher education is created and more students with and without IDD can share postsecondary educational experiences on college campus. 